\title{
Design for the Intermediate-level Oral CSL Class in the Postmethod Era
}

\author{
Cui Zheng \\ School of International Exchange, Shandong Normal University, Jinan, China
}

\begin{abstract}
The main purpose of the oral Chinese class is to improve students' Chinese speaking ability, which includes not only the speaking accuracy, fluency and complexity of Chinese language, but also the communicative ability in the Chinese social and cultural context. Second language teaching pedagogy has entered into a Postmethod era from the previous grammar-translation, audio-lingual, and communicative method etc. Under this background, this paper explores how to design the intermediate-level oral Chinese as a second language (CSL) class in the Postmethod era. Kumaravadivelu's (2003) Postmethod pedagogy, specifically the ten macrostrategies were adopted as the basis for the design of the intermediate-level oral CSL class. The exact tasks and activities such as quick share, speech-making, and cooperative activities are designed and scheduled in a detail for the students to improve their Chinese proficiency. The whole design should have some help and shed some lights on the oral CSL class teaching and learning in China.
\end{abstract}

Index Terms - postmethod era, Chinese as a second language, oral Chinese, ten macrostrategies

\section{INTRODUCTION}

What is the best method to teach a second or a foreign language? Wright (2010) reviewed the main second language teaching approaches and methods since the 19th century. The grammar-translation method, predominant from the 1840s to the 1940s focuses on the grammar. The audio-lingual method, which is influenced by the behaviorism emphasizes on the memorization of sentence structures. Communicative language teaching, which views language as a system for communication (Celce-Murcia, 2001), focuses on the actual use of the target language and the integration of language skills, which is still quite popular for the English as a foreign language teaching in China (Zheng, \&Chen, 2007). However, it is admitted that no single method or approach is omnipotent in every language classroom. These days, the Postmethod theory acclaimed by Kumaravadivelu (2003) is becoming favored in teaching a second or foreign language. The question is: does Kumaravadivelu's Postmethod theory fit Chinese as a second language (CSL) classroom, to be specific, oral Chinese class? If so, how to design an oral Chinese class based on Kumaravadivelu's Postmethod theory?

Gottlieb (2006) claimed that oral language could be viewed as "a purposeful, communicative action with emphasis on the specific use (the language function) or performance" (p. 45). Therefore, the target of oral language teaching should be to improve students' communicative ability. This is a comprehensive ability, which should include the accuracy, fluency and the appropriateness (Liu, 2001). When students' Chinese proficiency reaches the intermediate level, according to Liu (2001), the oral class should have a higher requirement on students' speaking speed and the use of variety of words. Intermediate oral Chinese class should focus on the integration of textbooks and the real communicative ability, and the interaction between the teacher and students as well. How to realize the interaction between the teacher and students? How to improve students' communicative ability? How to make students speak a lot, in other words, produce more output in the oral Chinese classroom? This research tries to design a syllabus for the intermediate-level oral Chinese class based on Kumaravadivelu's (2003) Postmethod theory, in order to maximize the effectiveness and efficiency of the class to improve students' oral Chinese ability.

\section{Postmethod Pedagogy}

Brown (2002) discussed the meaning of the word "methods". He claimed that English language teaching now has entered into an era that many factors such as teaching contexts and purposes, vast number of students' needs, learning styles and affective traits should be considered. The prepackaged method could possibly not able to solve all these problems. This new era, based on Kumaravadivelu's $(2003,2006)$ explanation, is the postmethod era. Kumaravadivelu (2006) visualized postmethod pedagogy as a system of three parameters: particularity, practicality, and possibility. Particularity means "a particular group of teachers teaching a particular group of learners pursuing a particular set of goals within a particular institutional context embedded in a particular sociocultural milieu" (Kumaravadivelu, 2001, p.538). In other words, the use of method should be flexible to different teaching situations and different students' needs. Practicality means teachers' sense of plausibility (Prabhu, 1990, cited in Kumaravadivelu, 2006). It refers to "teacher's skill in monitoring his or her own teaching effectiveness" (Kumaravadivelu, 2006, p. 172). Possibility is about whether the teaching could be carried on successfully with regarding the social issues, language ideology and learners' identity.

With all these three parameters considered, Kumaravadivelu $(2003,2006)$ further presented ten macrostrategies as the guiding framework for the second or foreign language teaching. These ten macrostrategies are: Maximize learning 
opportunities; facilitate negotiated interaction; minimize perceptual mismatches; activate intuitive heuristics; foster language awareness; contextualize linguistic input; integrate language skills; promote learner autonomy; ensure social relevance; and raise cultural consciousness.

Creating more and appropriate learning opportunities for students is very important in the student-centered teaching environment and in the oral Chinese class as well. Learning opportunities could happen inside the classroom, such as group work, teacher questioning, and games; it could also happen outside the classroom, such as social research, Chinese language corner etc. Chinese teachers should also enhance the learner-learner and learner-teacher interaction in class by assigning a topic to talk about, or a task such as making a traveling plan to let students do together. Language awareness can only be fostered and improved by the exposure to the target language and the use of it. Since all the foreign students are learning Chinese in China, it becomes easier for them to expose themselves to the Chinese environment by listening and speaking Chinese not only in the classroom but also in the society. Contextualizing students' linguistic input can be viewed as one way to cultivate students' language awareness. Role play or other inclass activities such as asking students to call the real travel agency could contextualize students' Chinese input and could also foster students' sense of different levels of language formality. Learner autonomy can be realized by the cooperation among students with tasks. During this process, students' creativity could be maximized as well as their Chinese proficiency. Social issues can be used in a perfect way as the topics in the oral Chinese class. Such popular issues among college students such as the balance between study and part-time job can be used for students to make the speech. Finally, in oral Chinese class, teachers can ask students share their own cultures, food, clothes, weather, cities etc. Usually students are very willing to introduce their own cultures. By doing this, students' Chinese listening and speaking ability are improved and their culture consciousness is raised too. In a word, almost all the ten macrostrategies can be used as guidance in oral CSL class. Based on these macrostrategies, a syllabus is designed for an intermediatelevel oral CSL class.

\section{INTERMEDIATE-LEVEL ORAL CSL CLASS DESIGN}

As mentioned above, when students' Chinese proficiency have reached the intermediate level, teachers should have a higher requirement towards students' oral output: accuracy, fluency, grammatical and lexical complexity, the communicative ability etc. This study tries to design a tentative syllabus and possible activities for the intermediate oral Chinese class to improve the teaching and learning efficiency and effectiveness.

The textbook used for the class is named “Elementary Spoken Chinese II” (汉语初级口语教程下册), written by Yang and Jia in 2007. Although students have reached the intermediate level, this book is still regarded as a good and suitable one for the oral class. Suppose there are two classes each week, 90 minutes in total and the whole semester includes 16 weeks. The goal for this class is to further improve students' oral Chinese internally (fluency, accuracy and complexity) and externally (social communicative ability in different social situation) through a series of tasks and activities.

Kumaravadivelu's postmethod pedagogy didn't mention the assessment, but in order to integrate the teaching and assessment and make the class more effective, an assessment framework was made for students.

TABLE I.

ASSESSING METHOD TOWARDS STUDENTS

\begin{tabular}{|l|l|l|l|l|l|l|l|}
\hline Attendance & Independent tasks & Cooperative tasks & Final exam & Improvement & Total \\
\hline \multirow{2}{*}{$10 \%$} & Quick share & $5 \%$ & Travel plan & $10 \%$ & $40 \%$ & $5 \%$ & $100 \%$ \\
\cline { 2 - 5 } & Speech & $10 \%$ & Social research & $20 \%$ & & & \\
\hline
\end{tabular}

This assessment includes both formative evaluation such as tasks and summative final exam to guarantee the objectivity and reliability of students' final scores.

Two kinds of tasks were designed for students to finish, independent tasks (quick share and speech making) and cooperative tasks (travel plan and social research). Jacobs and Hall (2002) claimed that in second and foreign language learning, based on several theorists' opinions (Liang, Mohan, \& Early, 1998; Olsen \& Kagan, 1992), cooperative learning has several advantages: "increased student talk, more varied talk, a more relaxed atmosphere, greater motivation, more negotiation of meaning, and increased amounts of comprehensible input" (p.53). Therefore, students are assigned to finish some tasks both independently and cooperatively could be beneficial for their Chinese improvement.

\section{A. Quick Share}

Quick share is a good way for students to share their thoughts and experiences while practicing their Chinese. There is no limitation for the sharing topics. Students could share anything they want, such as their families, their pets, their dreams, their photos, etc. No difficult words are needed. If the words are too difficult, photos or PPT could be used as the assistance. There must be questions for the listeners when they do the quick share. And time is limited within three minutes. Rubric is definitely used for the assessment. 
TABLE II.

RURRIC FOR THE QUICK SHARE

\begin{tabular}{|l|l|l|l|l|}
\hline $\begin{array}{l}\text { Whether } \\
\text { well prepared }\end{array}$ & $\begin{array}{l}\text { Pronunciation, } \\
\text { fluency and clarity }\end{array}$ & $\begin{array}{l}\text { Whether it is interesting, } \\
\text { and interactive }\end{array}$ & $\begin{array}{l}\text { Whether within } 3 \text { minutes } \\
\text { or not }\end{array}$ & Total score \\
\hline 1 point & 2 points & 1 point & 1 point & \\
\hline & & & & \\
\hline
\end{tabular}

After students finish the quick share, the teacher should give the feedback immediately, with both students' advantages and disadvantages. Quick share is a good activity used in the oral Chinese class. Kumaravadivelu's several macrostrategies are used: learning opportunities are created; interaction between students and teacher are enhanced; learners' autonomy is also promoted.

\section{B. Speech-making}

All students are supposed to make a speech based on the given topics. The reason why the topics are given is to control the width of words and content. Students' Chinese are not good enough to handle any topic. It could happen that the content might be too difficult to understand if the student is not familiar with that topic. The other reason is that the same topic could increase the repetition of some new words and new expressions, which makes it easier for students to memorize consciously and subconsciously. Topics should be related to the textbooks for not only speaking class but also reading or writing class. Here are some tentative topics for students to choose. The genre could be either narrative or argumentative.

TABLE III.

SEVERAL TOPICS FOR SPEECH MAKING

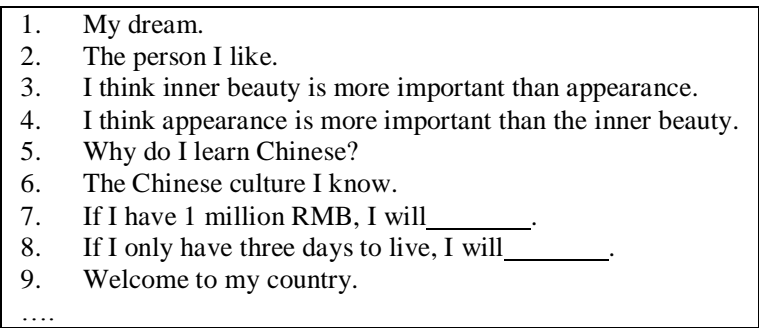

There are some requirements for students. Students need to choose the topic and finish writing it for the speech presentation at least one week ago. Then the teacher could have some time to check and give some revising ideas to students in order to make sure the speech is grammatically and lexically correct. The maximal time for the speech is three minutes and the whole speech manuscript is about 300 words. It is a speech presentation, so the students are not advised to read the manuscript or just memorize it mechanically.

TABLE IV.

RUBRIC FOR SPEECH PRESENTATION

\begin{tabular}{|c|c|c|c|c|c|}
\hline Whether well prepared & $\begin{array}{l}\text { Pronunciation, fluency } \\
\text { and clarity }\end{array}$ & $\begin{array}{l}\text { Whether the content is } \\
\text { interesting and logical }\end{array}$ & Interaction & $\begin{array}{l}\text { Whether within } \\
3 \text { minutes or not }\end{array}$ & Total score \\
\hline 2 points & 3 points & 3 points & 1 point & 1 point & \\
\hline
\end{tabular}

Teachers need to give the oral and written feedback immediately after students' presentation, just like what they do for the quick share in order to motivate the students. If necessary, the teacher can videotape each student's performance and show it to the students again at the end of the semester as a part of the digital portfolio. In addition, not like the quick share, which can be performed every class, speech presentation can be conducted in a fixed period of time, for instance, 3-5 students in each class time, thus students can compare and compete with each other in some sense.

\section{Travel Plan}

This is an interesting cooperative activity. Besides practicing students' oral Chinese, students can design the real travel plan and if possible, go for the real trip. Firstly, students need to form into several groups, with 3-4 members in each group. They can choose and negotiate by themselves to form their own group. However, for the class group discussion, the teacher can assign them into different group instead of letting students to form their own group. This grouping method is called Numbered Heads Together (Jacobs and Hall, 2002; Wright, 2010). Secondly, the teacher needs to explain in detail the design requirements for this travel plan. Each group needs to choose a city in China and make the adequate travel plan: When are you going to leave? How do you go to that city? If you take the train, what is the train number? How will you go to the train station? What is the ticket price? How will you purchase the ticket? How long does it take to arrive at your destination? Where will you stay in that city? What places of interest are you going to visit? What kind of belongings are you going to take? Questions like these need to be considered very carefully. In order to answer these questions, students must go to some Chinese websites, or ask their Chinese friends and discuss 
together. During the whole process, their Chinese language ability, and question-solving ability can be improved for sure.

After discussion and preparation for about one week, students are supposed to do the presentation in class, to show their plan to the whole class with the help of PPT or some other supplementary materials. The teacher and other classmates need to give suggestions to improve their travel plan. The whole presentation is supposed to finish within 20 minutes.

TABLE V.

RUBRIC FOR THE TRAVLE PLAN

\begin{tabular}{|l|l|l|l|l|l|}
\hline Preparation & $\begin{array}{l}\text { Fluency, pronunciation, } \\
\text { accuracy, grammar }\end{array}$ & $\begin{array}{l}\text { Mastery of content, } \\
\text { reasonable travel plan }\end{array}$ & Interaction, cooperation & Timing & Total score \\
\hline 2 points & 2 points & 3 points & 2 points & 1 point & \\
\hline & & & & & \\
\hline
\end{tabular}

\section{Social Research}

The purpose of this activity is to help the foreign students to adjust to the local life, and improve their Chinese communicative strategy and ability. There is no specific research topic for them, so each group needs to design their research and interview by themselves. The teacher needs to explain clearly what students need to do.

1) Firstly, each group needs to choose a topic as their social research title, such as Chinese lunar year, spare time of Chinese college students, etc. The selection of the topic is totally up to the students.

2) After setting down the topic, students need to decide the interviewees. At least two or three interviewees are needed with different ages, different genders and different careers. At least ten questions are needed for the interview.

3) A video camera is needed to make the record and for the after-interview presentation as well.

4) After all the above-mentioned prepared well, each group needs to talk with the teacher to further improve their research.

5) After the research and interview, each group needs to write down their research report and do the in-class presentation within 30 minutes with PPT and necessary videos and materials.

6) The teacher definitely needs to give the feedback and their score based on the rubric.

TABLE VI.

RUBRIC FOR THE SOCIAL RESEARCH

\begin{tabular}{|l|l|l|l|l|l|}
\hline Preparation & $\begin{array}{l}\text { Mastery of content, } \\
\text { significance of the research }\end{array}$ & $\begin{array}{l}\text { Fluency, pronunciation, } \\
\text { accuracy, grammar }\end{array}$ & $\begin{array}{l}\text { Interaction, } \\
\text { cooperation }\end{array}$ & Timing & Total score \\
\hline 2 points & 6 points & 3 points & 3 points & 1 point & \\
\hline & & & & & \\
\hline
\end{tabular}

\section{E. Some Other In-class Activities}

Besides all the above-mentioned tasks, some other in-class activities can also be used to maximize students' learning opportunities and make the whole class more effective.

1. Self-introduction

It is a routine that in the first class students need to introduce themselves to each other. Here is an activity which can make the introduction interesting and effective. Firstly, the teacher needs to write down on the blackboard what students need to do when introducing themselves to each other, such as their name, nationality, major, family, hobby and the reason coming to China etc. Then students form two circles: inside is a small circle while outside is a bigger one. Both students inside and in the bigger circle need to face each other and begin to talk, introducing themselves. After 30 seconds, students need to move and face a new classmate and talk again. In this way, each student has the chance to talk with at least half of their classmates. Each of them gets the chance to practice their Chinese and further know their classmates. After about 10 minutes, students are asked to sit back to their seats and the teacher gives each of them a blank paper. Students are asked to fold the paper and make it as a cone with their Chinese name written on one side. Then a name card is made and students are supposed to put their name card on their desk, so each of their classmates can see it. In order to realize this, it is better to put students sit in a "U" shape. Putting desks in a "U" shape is also convenient for in-class discussion. The significance of this activity is that interaction between students is enhanced; students can get familiar with each other; their oral Chinese are practiced a lot too.

2. Dice Game

In order to review the learned words or expressions, the teacher can lead students play this game. A dice is needed and the teacher needs to prepare plenty of questions with different numbers (1-6) as the question number. Then the teacher can ask students to play the dice and decide the question they have to answer. Groups of students can also compete with each other. The teacher may also need to prepare some small gifts to encourage the winner group. This is an interesting game to activate the students' participation and activeness.

3. Creative Speaking Activity 
For this activity, the teacher can show several slides of pictures consecutively with very simple object in each slide, such as a balloon, a bicycle, or just a bird. Students then need to talk with their group member for several minutes, connect these pictures and think out a story quickly. Then groups can share their stories with each other. This activity is a little difficult and challenging, but students can do it well with their imagination and cooperation.

4. Several Other games

In Wright's (2010) book, he mentioned several activities for ELL (English for Language Learners) class, which is evidently also available for the CSL class. Activities such as role play, songs and chants, and think-pair-share are all very meaningful and effective if used correctly in Chinese language class.

\section{DISCUSSIONS AND CONCLUSION}

Now if we look at back again the three parameters mentioned by Kumaravadivelu: particularity, practicality and possibility, we can find that this design of the intermediate oral CSL class could realize these three parameters well. Oral CSL class has its own particular goals for students to reach. Students need to improve their Chinese speaking proficiency through the oral class. All the activities designed must have the possibility for students to finish. In other words, it must be practical. All the tasks and activities should meet the ten macrostrategies Kumaravadivelu mentioned. The fact is that the quick share, the speech-making, the design of travel plan, the social research and all the other inclass activities can maximize the learners' learning opportunities, can facilitate negotiated interaction, can activate learners' intuitive heuristics, foster their language awareness and can promote learners' autonomy and put them in the social and cultural environment.

Wright (2010) emphasizes the importance of interaction in language class. He claimed that students' interaction with the teacher, their fellow classmates, and proficient language speakers within the sociocultural contexts is crucial for second language acquisition. Meanwhile, many researchers explained the strengths of task-based language teaching (e.g. Nunan, 1989; Beglar and Hunt, 2002). Ellis (2003) defined tasks as "activities that call for primarily meaning-focused language use" (p.3). Beglar and Hunt (2002) claimed that task-based teaching makes language use occurs in a natural and communicative context. As mentioned above, cooperative learning is also very beneficial for second and foreign language learning (Jacobs and Hall, 2002). In a word, it is very clear that different researchers focus on the different aspects of second and foreign language teaching. However, not matter it is about cooperative learning, class interaction or task-based teaching, all of the research essentially reaches a consensus with Kumaravadivelu's postmethod theory, i.e. Students' need should be put in the first place; Teachers should scaffold students to participate in the class and to maximize students' learning autonomy.

All the designs in this research are based on Kumaravadivelu's postmethod theory. However, in the implementation of these tasks and activities, there must be some expected or unexpected problems arising. Therefore, in the Postmethod era, carrying on these activities flexibly and paying more attention to the students' reactions and needs are the best ways to maximize the effectiveness and efficiency of the oral CSL class.

\section{REFERENCES}

[1] Beglar, D. \& Hunt, A. (2002). Implementing task-based language teaching. In J. C. Richards \& W. A. Renandya (Eds.), Methodology in language teaching: An anthology of current practice (pp. 96-106). Cambridge: Cambridge University Press.

[2] Brown, H. D. (2002). English language teaching in the "post-method" era: Toward better diagnosis, treatment, and assessment. In J. C. Richards \& W. A. Renandya (Eds.), Methodology in language teaching: An anthology of current practice (pp. 9-18). Cambridge: Cambridge University Press.

[3] Celce-Murcia, M. (2001). Teaching English as a second or foreign language. Bostion: Heinle \& Heinle.

[4] Ellis, R. (2003). Task-based language learning and teaching. Oxford: Oxford University Press.

[5] Gottlieb, M. (2006). Assessing English language learners: Bridges from language proficiency to academic achievement. Thousand Oaks, CA: Corwin Press.

[6] Jacobs, M. G. \& S. Hall. (2002). Implementing cooperative learning. In J. C. Richards \& W. A. Renandya (Eds.), Methodology in language teaching: An anthology of current practice (pp. 52-58). Cambridge: Cambridge University Press.

[7] Kumaravadivelu, B. (2001). Toward a postmethod pedagogy. TESOL Quarterly 35, 537-560.

[8] Kumaravadivelu. B. (2003). Beyond methods: Macrostrategies for language teaching. New Haven and London: Yale University Press.

[9] Kumaravadivelu. B. (2006). Understanding language teaching: From method to postmethod. Mahwah, New Jersey: Lawrence Erlbaum Associates, Publishers.

[10] Liang, X., Mohan, B. A. \& Early, M. (1998). Issues of cooperative learning in ESL classes: A literature review. TESL Canada Journal 15 (2), 13-23.

[11] Liu, X.Y. (2001). A review of studies on oral teaching for teaching Chinese as a foreign language. Language Teaching and Linguistics Studies 2, 27-33.

[12] Nunan, D. (1989). Designing tasks for the communicative classroom. Cambridge: Cambridge University Press.

[13] Olsen, R. E. W-B. \& Kagan, S. (1992). About cooperative learning. In C. Kessler (Ed.), Cooperative language learning: A teacher's resource book (pp. 1-30). Englewood Cliffs, NJ: Prentice Hall.

[14] Prabhu, N.S. (1990). There is no best method-why? TESOL Quarterly 24, 161-176.

[15] Wright, W. E. (2010). Foundations for teaching English language learners: research, theory, policy \& practice. Philadelphia, PA: Caslon. 
[16] Yang, J. Z. \& Jia, Y. F. (2007). Elementary spoken Chinese II . Beijing: Beijing University Press.

[17] Zheng, Y. Q. \& Chen, M. H. (2007). English teaching in the postmethod era. Foreign Languages and Their Teaching 10, 33-35.

Cui Zheng was born in Shandong in 1982. She received her Ph.D. in English education from Korea University in Seoul, South Korea in 2010. Her research interest lies in second language acquisition and language assessment. She is now a lecturer teaching in School of International Exchange, Shandong Normal University, China. She has several published articles in the field of TEFL and TCSL (teaching Chinese as a second language). 